\title{
IAMJ
}

INTERNATIONAL

AYURVEDIC

MEDICAL JOURNAL

\section{A RANDOMIZED COMPARATIVE CLINICAL STUDY ON LODHRADHI LEPA AND ARJUN TWAK LEPA WITH JALOUKAVACHARANA IN THE MANAGEMENT OF MUKHADUSHIKA (ACNE VULGARIS)}

\author{
Sagar Rathod ${ }^{1}$, N. B. Mashetti ${ }^{2}$, P. G. Gannur ${ }^{3}$, Rakeshkumar Gujjar ${ }^{4}$ \\ ${ }^{1}$ Post Graduate Scholar, Department of Shalyatantra \\ ${ }^{2}$ Professor and HOD, Department of Shalyatantra \\ ${ }^{3}$ Associate Professor, Department of Shalyatantra, \\ ${ }^{4}$ Assistant Professor, Department of Shalyatantra. \\ BLDEA’s AVS Ayurveda Mahavidyalaya, Vijayapur, Karnataka, India
}

Corresponding Author: sagar.rathod34@gmail.com

\section{https://doi.org/10.46607/iamj0908102020}

(Published online: October 2020)

Open Access

(C) International Ayurvedic Medical Journal, India 2020

Article Received:12/09/2020 - Peer Reviewed: 28/09/2020 - Accepted for Publication:03/10/2020

\section{(D) Check for updates}

\section{ABSTRACT}

Mukhadushika is the most troublesome and most common skin care problem. The symptoms of Mukhadushika resembles with Acne Vulgaris. Objective: The present study was to evaluate the comparative effect of Lodhradilepa and Arjuna twak lepa with Jaloukavacharana in the management of Mukhadushika. Methods: 40 patients were randomly selected and divided into 2 groups. Results: Both the groups showed statistically significant results on all assessment criteria. On comparison between 2 groups, there is no significant difference in assessment criteria except in the size in which Group-2 was more effective than Group-1 and Number of pidaka in both groups found to be insignificant. Interpretation and conclusion: Jaloukavacharana serve as a Shodhana karma here as there is involvement of Rakta dhatu in the Samprapti \& Lepa is one of the treatment modalities for Mukhadushika mentioned in classics. Both Arjuna lepa and Lodhradi lepa along with application of Jalouka showed statistically highly significant on all the assessment criteria like vedana etc. GAGS Score and IGA criteria 
except in the size in which Group-2 was more effective than Group-1 and Number of Pidaka in both groups found to be insignificant.

Keywords: Mukhadushika, Lodhradilepa, Arjuna Twak Lepa, Jaloukavacharana

\section{INTRODUCTION}

Mukhadushika is commonly called as Youvanapidaka as it affects to mainly adults. According to Sushruta, Shalmali Kantaka like eruptions on the face due to vitiation of kapha, vata \& rakta and are characterized by Saruja, Ghana, Medogarbha known as Mukhadushika or Youvanpidikaor Tarunya pidika ${ }^{1}$. The explanation of Mukhadushika is similar with description of "Acne vulgaris" the surface areas of the skin that contains the most amounts of sebaceous glands will be the areas prone for acne vulgaris breakouts. This includes the back, face, and upper portion of the chest. The most common causes of acne vulgaris are hormone fluctuations; excess sebum production in the pelosebacious units, in few cases genetics has been shown to play a role. In modern medicine the treatment mainly includes prolonged use of antibiotic, comidolytics and anti-inflammatory agents. Though, these medicines are better treatment options for acne management, the side effects of these medications such as increase in frequency and severity of skin dryness, scaling, erythema, and burning, stinging, itching and bacterial resistance limits their use $^{2}$.In Ayurveda Mukhadushika is treated mainly by Shodhana (purification of body) and Shamana (conservative treatment) or combination of both. As the involvement vitiation of Rakta in the Samprapti of Mukhadushika, Raktamokshana with Jaloukavacharana may benefit and the efficacy of local application of Lodhradi lepa and Arjun Twaklepa has been proven previously on Mukhadhushika ${ }^{3}$ hence the combination of Shodhana and Shamana together may give synergetic effect in curing Mukhadushika .For Mukhadushika, Lepa as treatment modality acts quick and locally but not long-lasting leading to relapse of the disease. The administration of shodhana therapy may benefit by removing vitiated doshas from the site, it is also said that action of shamana aushadi will increase after shodhana, Hence an attempt is made in the present study by adopting Jaloukavacharana in both the groups then followed by Lodhradi lepa in one group \& Arjun twak lepa in other group for external application for 15 days, to rule out the synergetic action of both Shodhana \& Shamana effect in Mukhadushika.

Materials and Materials: Totally 40 patients of Mukhadushika selected and divided into two groups, Group $1-20$ patients and Group $2-20$ patients. Complete history and clinical evaluation of the patients of Mukhadhushika recorded in the specially designed case sheet. Subjective and objective parameters were used to assess the clinical response in both the groups. The patients were assessed on before treatment $\left(1^{\text {st }}\right.$ day), after treatment ( $16^{\text {th }}$ day), Follow up on $23^{\text {rd }}$ day and $31^{\text {st }}$ day.

Group 1- Jaloukavacharana followed by Lodradi le$p a^{4}$.

Group 2 - Jaloukavacharana followed by Arjun twak lepa ${ }^{5}$.

\section{Preparation of Lodhradilepa}

Drugs- Lodhra, Dhanyaka, Vacha

Each drug is pounded into fine powder and mixed in equal parts and made paste with lukewarm water.

\section{Preparation of Arjun twaklepa}

Drug-Arjun twak

Arjun twak is pounded into fine powder and made paste with milk.

Jaloukavacharana: Activated Nirvishajaloukas are taken and applied to most affected part and temperature is maintained my putting wet gauze over it and sucking is observed until 40-45 min. Used Jaloukas are vomited by putting Haridra/Saindhavalavana over the face.

\section{Source of Data:}

Sample Source: 40 patients diagnosed with Mukhadushika are taken for the study from OPD/IPD of B.L.D.E.A's AVS Ayurveda Mahavidyalaya Hospital and research center, Vijayapura. 


\section{Inclusion Criteria}

1. Age group between 16 to 35 years irrespective of gender.

2. Patients diagnosed with the clinical symptoms of Mukhadushika i.e. Shalmali Kantaka, Saruja, Ghana, Medogarbha.

\section{Exclusion Criteria:}

1. Patients with systemic illness and hormonal disorders.

2. Patients who are Allergy to Lepas.

3. Pregnant women.

4. Patients of Krusha or underweight.

5. Patients with severe Anemia

\section{Observation and Results}

\section{Effect on Vedana (Pain)}

Group 1-Before treatment mean score and standard deviation of Vedana of Pidaka was $2.30 \pm 0.801$ which reduced to $0.80 \pm 0.768$ after treatment, showing $65 \%$ reduction. It was statistically significant at the level of $\mathrm{P}<0.01$. Group 2- Before treatment mean score and standard deviation of Vedana of Pidaka was $2.65 \pm .0587$ which reduced to $1.15 \pm 0.489$ after treatment, showing $56.6 \%$ reduction. It was statistically significant at the level of $\mathrm{P}<0.001$.

\section{Effect on Srava of Pidaka:}

Group 1- Before treatment mean score and standard deviation of Srava of Pidaka was 2.25 \pm 2.049 which reduced to $0.40 \pm 0.503$ after treatment, showing $82 \%$ reduction. It was statistically significant at the level of $\mathrm{P}<0.01$. Group 2- Before treatment mean score and standard deviation of Srava of Pidaka was 2.15 \pm 0.745 which reduced to $0.25 \pm 0.444$ after treatment, showing $88.37 \%$ reduction. It was statistically significant at the level of $\mathrm{P}<0.01$.

\section{Effect on Number of Pidaka:}

Group 1- Before treatment mean score and standard deviation of Number of Pidaka was $2.95 \pm 0.224$ which reduced to $2.40 \pm 0.598$ after treatment, showing 18.6 $\%$ reduction. It was statistically not significant at the level of $\mathrm{P}<0.05$. Group 2- Before treatment mean score and standard deviation of Number of Pidaka was $3.00 \pm 0.00$ which reduced to $2.45 \pm 0.510$ after treatment, showing $18.3 \%$ reduction. It was statistically not significant at the level of $\mathrm{P}<0.05$.

\section{Effect on Size of Pidaka:}

Group 1-Before treatment mean score and standard deviation of Size of Pidaka was $1.95 \pm 0.826$ which reduced to $1.25 \pm 0.444$ after treatment, showing 35.89 $\%$ reduction. It was statistically not significant at the level of $\mathrm{P}>0.05$. Group 2-Before treatment mean score and standard deviation of Size of Pidaka was $2.10 \pm 0.641$ which reduced to $1.05 \pm 0.224$ after treatment, showing $50 \%$ reduction. It was statistically significant at the level of $\mathrm{P}<0.001$.

\section{Effect on Vivarnata of Pidaka:}

Group 1-Before treatment mean score and standard deviation of Vivarnata of Pidaka was $2.45 \pm 0.887$ which reduced to $0.95 \pm 0.510$ after treatment, showing $61.22 \%$ reduction. It was statistically significant at the level of $\mathrm{P}>0.05$. Group 2- Before treatment mean score and standard deviation of Vivarnata of Pidaka was $2.25 \pm 0.786$ which reduced to $0.70 \pm 0.657$ after treatment, showing $8.88 \%$ reduction. It was statistically significant at the level of $\mathrm{P}<0.001$.

\section{Effect on Global acne Grading system:}

Group 1- Before the treatment mean score and standard deviation of Global acne Grading system was $21.25 \pm 5.803$ which reduced to $11.55 \pm 3.052$ after the treatment, showing $45.64 \%$ reduction. It was statistically significant at the level of $\mathrm{P}<0.01$. Group 2- Before the treatment mean score and standard deviation of Global acne Grading system was 22.70 \pm 3.686 which reduced to $10.75 \pm 3.307$ after the treatment, showing $52.64 \%$ reduction. It was statistically significant at the level of $\mathrm{P}<0.001$.

\section{Effect on Investigators Global Assessment:}

Group 1- Before the treatment mean score and standard deviation of Investigators Global assessment was $2.60 \pm 0.754$ which reduced to $1.50 \pm 0.688$ after the treatment, showing $42.30 \%$ reduction. It was statistically significant at the level of $\mathrm{P}<0.001$. Group 2Before the treatment mean score and standard deviation of Investigators Global Assessment was $2.45 \pm 0.759$ which reduced to $1.45 \pm 0.605$ after the treatment, showing $40.81 \%$ reduction. It was statistically significant at the level of $\mathrm{P}<0.001$. 
Overall Effect: The overall effect in Group 1 showed highly significant result with mean score \& standard deviation before treatment was $11.90 \pm 2.922$ respectively and $5.80 \pm 1.67$ after treatment with overall reduction of $51.3 \%$. The overall effect in Group 2 showed highly significant result with mean score \& standard deviation before treatment was $12.15 \pm 2.41$ respectively and $5.60 \pm 1.57$ after treatment with overall reduction of $54 . \%$.

\section{DISCUSSION}

Mukhadooshika in modern view has similarity with Acne Vulgaris which is called to be a Physically and Psychologically scarring disease. In this disease patients have greater impairment in mental health and associated with psychological disturbances like embracement, anxiety. In the study many of the patients had Manasika lakshanas like Krodha, Ayasa, Shoka, which aggravates Vata Dosha. Jalaukavacarana being a bio-purificatory method removes deeply seated toxins by letting out blood, clearing Srotasa and pacifying vitiated Dosha. As Jalaukavacarana removes vitiated Pitta/Rakta, which causes reduction in Paka,

Daha and number of Pidakas. It also reduces the pooled blood and pus which results in purification of Srotas. Lodradi Lepa are having the predominance of Tikta, Katu and Kashaya Rasa, Laghu Guna, KatuVipaka and UshnaVirya. These properties alleviate KaphaDosha. It is capable of pacifying vitiated Vata Dosha by its Madhura Rasa, Snigdha Guna, Ushna Veerya and Madhura Vipaka. Due to the presence of Madhura, Tikta, Kashaya Rasa, Snigdha Guna and Sheeta Virya it alleviates Pitta Dosha. Arjuna which has Kashaya rasa, Sheetaveerya does Shamana of Kapha and Pitta. Raktashodaka property of Arjuna acts on the causative factor of Mukhadushika. Thus, Ksheera which has Madhurarasa, Sheetaveerya and Vatapittashamaka property provides an added effect to this yoga. Flavonoids exhibit Anti-Inflammatory activity. Tannins exhibit antibacterial property. Overall, both the groups have shown highly significant results in all the parameters except in number of Pidakas and size of Pidaka.

\section{CONCLUSION}

The Statistical analysis the study reveals there is no significant difference between Jaloukavacharana followed by Lodhradilepa and Jaloukavacharana followed by Arjuntwaklepa are having Qualitative Equanimity effect of the treatment on disease Mukhadushi$k a$.

\section{REFERENCES}

1. Kaviraj Ambikanayadatta Shastry, Sushruta Samhita vol 1, reprint 2014, Varanasi; Chaukambha Sanskrit Sansthan; nidanasthana, 13-chapter, 38 shloka, p 372.

2. Sachin Anil Upasani, et al, Review on Yuvanapidika vis-à-vis Acne Vulgaris, IJPPR. Human, 2016; vol.5(3): p 77-94.

3. http://www.iamj.in/posts/images/uploads/4034_4040.p df.

4. Acharya Sri Radhakrishna Parashara, Sharangadharasamhita, reprint 1961, Kolkata, Shri Baidyanatha Ayurveda Bhavana Pvt. Ltd, uttarakhanda, 11chapter, 11 shloka, p 539.

5. Madham Shetty et al, Yogaratnakara vol 2, $1^{\text {stedition, }}$ reprint 2008, Varanasi, Chaukhambha Sanskrit Series Office; uttarardha, chap 24, shloka 123-124, p 1019.

\section{Source of Support: Nil \\ Conflict of Interest: None Declared}

How to cite this URL: Sagar Rathod et al: A Randomized Comparative Clinical Study On Lodhradhi Lepa And Arjun Twak Lepa With Jaloukavacharana In The Management Of Mukhadushika (Acne Vulgaris). International Ayurvedic Medical Journal \{online\} 2020 \{cited October, 2020\} Available from: http://www.iamj.in/posts/images/upload/4622_4625.pdf 